\title{
Labour
}

Journal of Canadian Labour Studies

Le Travail

Revue d'Études Ouvrières Canadiennes

\section{Valerie Korinek, Prairie Fairies: A History of Queer Communities and People in Western Canada, 1930-1985}

\section{Nadine Boulay}

Volume 85, printemps 2020

URI : https://id.erudit.org/iderudit/1070914ar

DOI : https://doi.org/10.1353/1lt.2020.0013

Aller au sommaire du numéro

Éditeur(s)

Canadian Committee on Labour History

ISSN

0700-3862 (imprimé)

1911-4842 (numérique)

Découvrir la revue

Citer ce compte rendu

Boulay, N. (2020). Compte rendu de [Valerie Korinek, Prairie Fairies: A History of Queer Communities and People in Western Canada, 1930-1985]. Labour / Le Travail, 85, 297-299. https://doi.org/10.1353/ltt.2020.0013 d'utilisation que vous pouvez consulter en ligne. 
Valerie Korinek, Prairie Fairies: A History of Queer Communities and People in Western Canada, 1930-1985 (Toronto: University of Toronto Press 2018)

In PRAIRIE FaIRIES: A History of Queer Communities and People in Western Canada, Valerie Korinek draws from an extensive array of archival materials and oral history interviews that provide a glimpse into the social, political, and cultural worlds of queer people living in five major urban centres - Winnipeg, Saskatoon, Regina, Edmonton, and, briefly, Calgary - from 1930 to 1985 . This study contributes to ongoing efforts to reveal or recover past queer subcultures that may be less obvious or legible as queer, in this case, the histories of gay, lesbian, and queer experience across the Canadian prairies. These prairie cities in Manitoba, Saskatchewan, and Alberta are not known for being queer hubs like Vancouver, Toronto, and Montreal, cities that have long been associated with visible queer communities, "gaybourhoods," political activism, and internationally known Pride festivals. Prairie Fairies refutes the representation of queer community and activism as possible and sustainable only in specific urban centres, and illustrates the ways that gay, lesbian, and queer people have made communities not in spite of where they live, but that were enabled though the realities of prairie life.

Prairie Fairies is a major contribution to Canadian LGBT studies and queer historiography that challenges the "[...] misperception that queer people did not live in the prairies, and that queer communities did not form in prairie cities." (13) Korinek's regional and multi-city approach puts spatiality and migration in the foreground, capturing the "[...] movement from small towns and farms into western cities, as well as the movement and interplay between cities." (9)
This approach captures many nuances of movement and migration across the prairies between 1930 and 1985: movements of people, ideas, and politics within individual cities: from informal cruising locations to university campuses; to movements between cities and within provinces, allowing a comparative analysis of queer cultures in cities like Saskatoon and Regina; as well as how the movement of people and ideas on the prairies intersected with and responded to gay, lesbian, and queer politics on a national scale.

Comparable to studies in the U.S., queer historiography in Canada has largely focused on LGBTQ communities and political activism in large cities, with rural areas and the 'flyover country' of the prairies and the Midwest equally cast as monolithically heteronormative and therefore devoid of any presence of queer subcultural or political history. While the general lack of scholarship on queer prairie life does not signify its absence, it does, however, require methodological creativity to find nuanced evidence of its existence. This methodological creativity is particularly evident in Part One, where Korinek highlights a range of queer cultural practices in Winnipeg, Regina, and Saskatoon from 1930 to 1969 , before the proliferation of visibly gay, lesbian, or queer activism, and before the words gay, lesbian, and queer were widely used as markers of identity.

Evidence for these queer prairie histories - particularly during the pre-war period - are understandingly "fragmentary and episodic," limited by the availability and unwillingness of many gay, lesbian, or queer people of this earlier generation to share their stories. Korinek addresses the ways that gender, race, and class have historically shaped the social mobility of gay, lesbian, and queer people. Women were restricted from many public spaces, many opting for private house parties 
and other spaces that are more difficult for historians to access. In Part One we see examples of sexual cultures of white and middle-class gay men during the 1930 s, gathering informally in parks, on university campuses, in downtown areas, cocktail bars, and other establishments. While these activities were risky, they also functioned as informal neighbourhoods that would enable other men to meet one another. These strategies were not necessarily available to women or to people of colour. Informal queer spaces such as the campuses of Winnipeg and Saskatoon were also sites of queer sexual cultures and socializing decades before the student movements of the 1960s and 70 s, with cohorts of gay and lesbian professors and students respectively mingling with one another, often 'in plain sight'.

Historical narratives of queer migration that presume the necessity of moving from a rural to urban context in order to find community contribute to assumptions about the prairies as monolithically non-urban, and as a point of departure, not a destination. In fact, the book asserts that many interviewees and key figures in known queer circles across prairie cities were locals who drew upon their insider knowledge of local norms to find others, build networks, and organize politically. Prairie Fairies pushes us to consider the particular legacy of colonial settlement on the prairies. This is a history at times characterized by an "ability to endure" or survivalist work ethic that is influenced by the "necessity of cooperation" between men and women and evidenced in a general "'get'er done" attitude" that shaped the social worlds of gay, lesbian, and queer Canadians.

Part Two follows forms of community building and cultural organizing, in Winnipeg, Saskatoon, Regina, Edmonton, and Calgary from the 1970s to 1985 , ending with the beginning of the
HIV/AIDS crisis hitting the prairie provinces, which prompted a different cycle of queer activism in response. This section examines the generational cohort that came of age during the 1970s and 80 s, and developed into a more public and visible demographic, establishing an unprecedented amount of formal queer spaces, organizations, groups, print and cultural materials.

Part Three follows the same span of time but focuses on the public forms of resistance and political organizing made possible through the expansion of queer space. Provincial human rights cases, bar and bathhouse raids, and examples of de jure and de facto homophobia highlight the intense pushback gay and lesbian prairie dwellers experienced owing to this increased visibility.

Accounting for regional changes over time and the relationships between different socio-historical scales (between cities, provincial versus national), Prairie Fairies understands LGBT history on the Canadian prairies as unfolding within a longue durée, refuting the positioning of private and more discrete forms of queer placemaking from the 1930 s to 1960 s as pre-or-apolitical. In fact, she makes the claim that "for [...] those active from the 1930 s through to the 1960 s, the daily resistance of living openly gay and lesbian lives in a prairie city would be sufficiently political." (65) Korinek suggests that the "discretionary practices" used by gay men and lesbians to navigate their social worlds from the 1930 s to late ' 60 s - while "fundamentally unhealthy," are often interpreted as indicative of a person who is closeted. (340) Prairie Fairies resists this binary logic of out/closeted as a framework for interpreting queer history that often neglects the ways that gender, race, and class enable or inhibit one's ability to do either. Nor does it account for the ways that queer experiences are always already contingent upon time and place. 
While it appears at first as if Prairie Fairies might follow a traditional and chronological approach to queer history, Korinek consistently reminds us that it is that very epistemic logic that makes locating non-apparent queer experiences so difficult, as it presupposes a political and spatial trajectory of progress that in many ways mirrors a coming out story. As a highly influential and important product of gay liberation politics in the 1970 s, the rhetoric of 'coming out' encouraged thousands of queer people to stop living in the closet, prompting mass migrations to major urban centres; most of which had pre-existing queer subcultures. Scholarship has also had a tendency to overemphasize the idea that movement from rural to urban; shifting from a repressed past to a hopeful future; closeted to "out and proud," are one and the same. Korinek argues that these tendencies contribute to the limited imagination of the prairies as a region blanketed only by farms and a legacy of homophobia. Prairie Fairies resists some of these historiographical trends, asking questions specific to a prairie locales and identities: What kinds of social spaces and connections were enabled through prairie life and prairie identity? How did the location and geography of the prairies vis-à-vis the U.S. and the rest of Canada shape the transfer of ideas and networks between queer scenes? And while it was known that queer cultures existed in cities like Toronto, what were the factors that made people stay?

As evidenced in excerpts from 80 interviews ( 31 of which were conducted by the author), gay, lesbian, and queer people have utilized a range of tactics to navigate their social worlds and to find one another, even in environments that appear to be unfriendly or outright hostile. Those familiar with gay and lesbian history in Canada will undoubtedly recognize the names of some of the individuals profiled: this includes, Chris Vogel, Richard North, and Gens Hellquist, all of whom have spent a significant amount of their lives in the public eye and are openly identifiable as activists. While this is the first longrange and regional study of queer history on the Canadian prairies, Korinek makes clear that there are many gaps left to fill, particularly in terms of including more stories from women and Indigenous people and communities. Unsurprisingly, and thanks to the proliferation of gay and lesbian political organizing, literature, and the declaration of more affirming identity politics, there is far more content available that highlights queer experience in prairie cities after 1969, not to mention more people around to talk about it. Accessing earlier histories is hindered not only by the passage of time and dearth of available witnesses, but also by the dismissal of certain queer experiences as pre-or-apolitical. While the majority of interviewees recruited were white gay men - a common occurrence that in part reflects how experiences of gender, race, and class profoundly shaped the social mobility of queer people - their stories uncover multiple "geograph[ies] of queer socializing." (52-53) These geographies provided the context for a range of sexual practices and expressions of gender nonconformity, in both private and public spaces, long before the days of gay liberation.

Nadine Boulay

Simon Fraser University

\section{Cecil Foster, They Call Me George: The Untold Story of Black Train Porters and the Birth of Modern Canada (Windsor: Biblioasis 2019)}

The RAILroAd, metaphorically and literally, has figured prominently in nineteenth and twentieth centuries Black history in North America. The 